\title{
Food Expired Date Reminder Research in the Kitchen
}

\author{
Xiaoguang Huang ${ }^{1, a}$, Jiaci Xie ${ }^{2, b}$ \\ ${ }^{1}$ School of Architecture and Art Design Hebei University of Technology Tianjin, China \\ ${ }^{2}$ Hebei University of Technology City College Tianjin, China \\ a9012020@qq.com, bJacy1988@163.com
}

Keywords: Kitchen, Food reminder, Expired date

\begin{abstract}
Food waste has become a common phenomenon in a family who has children need to bring up, the reason cause that happen is family normally would buy more food and keep in the fridge and easily forget the food expired date. To help the family solve this problem not only in finance but also from a moral level, we came up with an idea after a lot research on users, products and environment, to design a food reminder that could assist family to easily remember the expired date of all kinds of food.
\end{abstract}

\section{Introduction}

This project aims at working in the contemporary kitchenware for the worldwide home wares market. Universal home wares supermarkets or companies who concentrate on selling kitchenware and food products would be interested in this project. And some organizations on food area or sector would become potential supporters or useful information suppliers to help working further for this project.

\section{Proposition \& Proposal}

Food waste identified as a serious and considerable problem attracted environmental, economic, ethical and social concern. Hence, a government-funded organization "Waste \& Resources Action Programme" (WRAP) has published in 2000 to change this situation. According to WRAP reports, 7.2 million tonnes of food and drink has been thrown away from households every year, which could be evitable.

Food waste is a general and huge problem, which is involved packaging, agriculture, environment, business, and households. While, to narrow down the scope of design, in this project it mainly focuses on household area. The survey conducted by WasteAware(2010) mentions that they guessed an average household would throw away $£ 50$ worth of food each month, according to the respondents they have had. Hence, to reduce food waste and save money for households would be this project opportunity to develop and design. To make a specific proposition, a user-task-environment (UTE) has been created after collected and analysed the data from several participants in the interview recorded in the logbook.

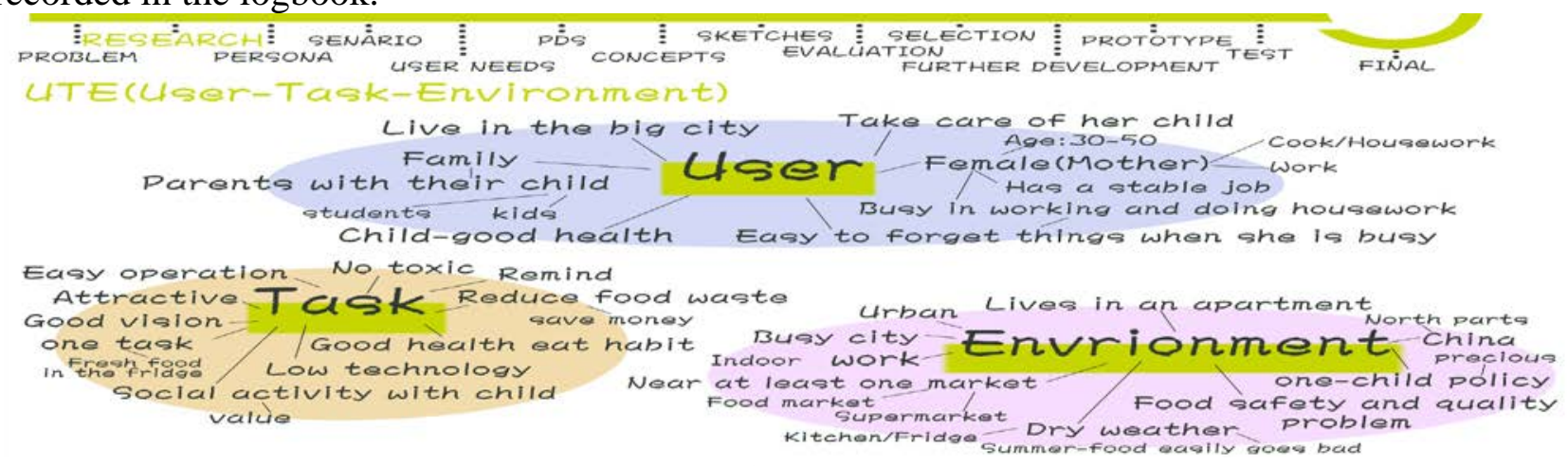

Figure 1 User Task Environment (UTE)

Figure1 
From figure 1, this project user is identified to be a two-parents-family who has children and both of parents have full-time jobs. They live in an apartment where is close to at least one market in their neighbourhood in the north parts of Chinese cities. The users' problem would be too busy in working and taking care of the family as to forget the food expired date and lead to unnecessary waste.

Based on UTE data showed above, this project proposal is to design a food product for families who have children. Food would be mainly concentrate on fresh food stored in the fridge which more easily goes bad. The product must be easy to operate and with a clear eye-catching interactive design and could remind users of food shelf-life on time. Hence, in a broad view, the main purpose of this product is to reduce unnecessary food waste, save money and produce a healthier lifestyle for users. In specific, this product could remind the fresh food shelf-life within a maximum 6 days and stick on the outside fridge door like a fridge magnet.

\section{Rationale and Evidence}

The data of user interview recorded in the logbook presents that students, old retired ladies, singles, family of adults are not the perfect users for this project. They all seldom throw away food based on different reasons, such as have a plan, finance problem, or eat expired food. While, only the families with children stated that they really discard a lot of expired food even if it looks in a good condition.

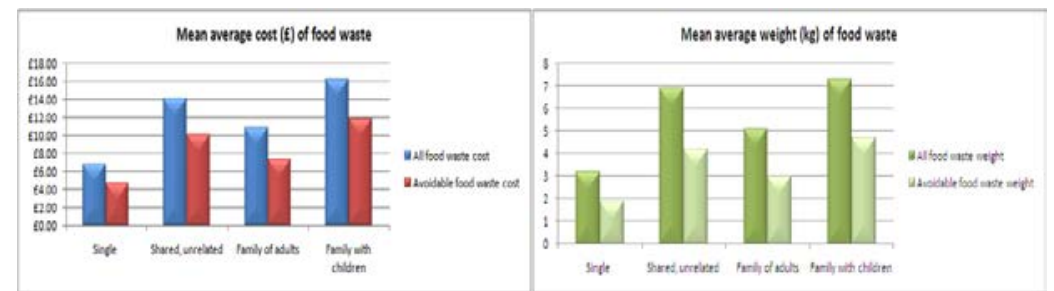

Figure 2

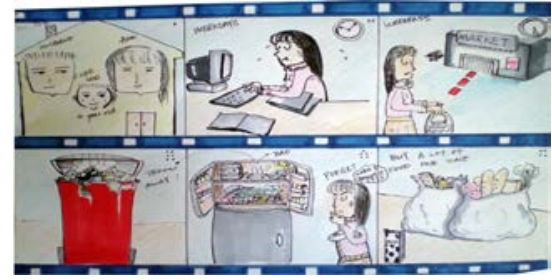

Figure 3

Figure2: Graphs showing the mean average cost and weight of food waste by household composition. Source: WRAP, the Food we waste Report The figure reported by WRAP also proved that family with children would waste more food and money than other groups of users. For that reason, the final user would be family with children.

Figure 3: Scenario shows the problem of food waste getting from interview data analysis A scenario has been designed to illustrate on what is the main problem leads them to throw away food.

Food has been categorized into 6 different types based on the book of Cadwallader, K., Weenen, H., (2002), for example, fruit and vegetables, meats and poultry, milk and dairy products, fish and seafood, bread and bakery products, orange and fruit juices. Meats tend to store in the freezer and user less care about the expired date on these products. Hence, fresh food which is more easily goes bad would need to be designed in this project. 


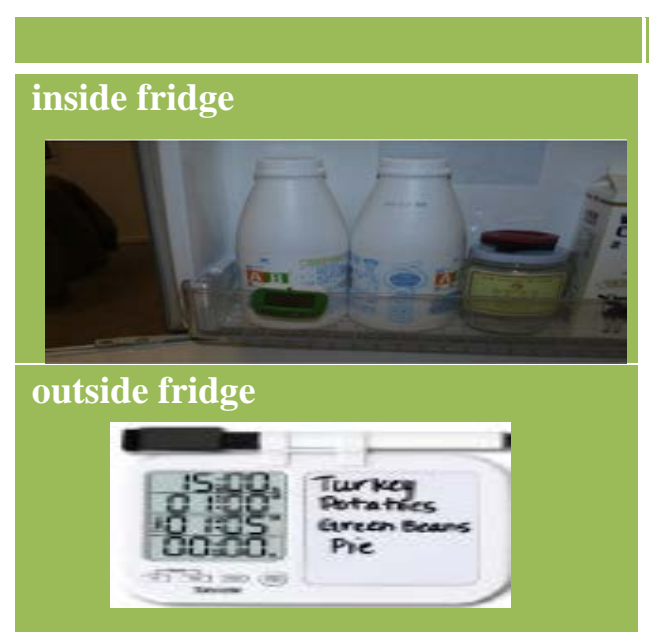

\begin{tabular}{|l|l|}
\hline $\begin{array}{l}\text { advantages } \\
\text { Small, easy to carry, }\end{array}$ & $\begin{array}{l}\text { Only can solve one food at one time, } \\
\text { have to buy loads of this products- } \\
\text { product, simple } \\
\text { technology, go with food } \\
\text { price would be high, open the fridge } \\
\text { would waste electric power, small } \\
\text { screen, food in the fridge is colourful } \\
\text { may be not easy to find this product }\end{array}$ \\
\hline $\begin{array}{l}\text { Take a note, record lots } \\
\text { of food at one time, a } \\
\text { reminder clock, save } \\
\text { time on searching the } \\
\text { food inside fridge, clear } \\
\text { screen, organised }\end{array}$ & $\begin{array}{l}\text { Price, complicated } \\
\text { programming, weight, annoying } \\
\text { alarming sound, fall off from the } \\
\text { fridge door }\end{array}$ \\
\hline \multicolumn{1}{c|}{ Chart 1}
\end{tabular}

Compared two existing products above, the products on fridge door seem to have more opportunities to design, develop and innovate. As it has been shown from the pictures above, game and bomb are always designed to countdown the time in order to letting their players feel tension and pressure during the game. Hence, to arouse user's attention and concern on food waste, interface designed could introduce countdown action to reflect that time is in an urgent situation.

The aim of creating ergonomic prototype is to design a better and comfortable condition for users to use and handle this product. Three parts have been taken into consideration in this product, which are disc size, date branch size and the size of the handle on date branch.

To make this product working better, ergonomic test and evaluation have been taken to analyse and improve the details on this product, which are date branches test, different diameters of outside discs test, refrigerator size study and final users' feedback. This collected data indeed helps to evaluate the product and propose new design and improvements.

To find out a perfect size for the disc, three 3mm thickness boards have been built into 100mm, $120 \mathrm{~mm}$ and $140 \mathrm{~mm}$ diameter circles. 7 users have been interviewed to see which size of the disc they like best and would like to put it on the fridge.

\begin{tabular}{|c|c|c|c|c|c|c|c|}
\hline $\begin{array}{l}\text { Users/ } \\
\text { size }\end{array}$ & $\begin{array}{l}\text { User } \\
\text { one }\end{array}$ & $\begin{array}{l}\text { User } \\
\text { two }\end{array}$ & User three & User four & User five & User six & User seven \\
\hline $\begin{array}{c}100 \mathrm{~m} \\
\mathrm{~m}\end{array}$ & $\begin{array}{l}\text { Too } \\
\text { small }\end{array}$ & small & small & Too small & $\begin{array}{l}\text { May not look } \\
\text { good when puts it } \\
\text { on the fridge }\end{array}$ & $\begin{array}{l}\text { Do not } \\
\text { like the } \\
\text { small size }\end{array}$ & $\begin{array}{c}\text { Too small to } \\
\text { read the words } \\
\text { on it }\end{array}$ \\
\hline $\begin{array}{c}120 \mathrm{~m} \\
\mathrm{~m}\end{array}$ & $\begin{array}{c}\text { Size is } \\
\text { ok }\end{array}$ & It is ok & $\begin{array}{l}\text { Still a little } \\
\text { bit small for } \\
\text { me }\end{array}$ & $\begin{array}{c}\text { This size } \\
\text { would be } \\
\text { nice }\end{array}$ & $\begin{array}{l}\text { Compare the size } \\
\text { with fridge, this } \\
\text { one is still small }\end{array}$ & No & This one is ok. \\
\hline $\begin{array}{c}140 \mathrm{~m} \\
\mathrm{~m}\end{array}$ & $\begin{array}{l}\text { Too big } \\
\text { for me }\end{array}$ & $\begin{array}{l}\text { Like } \\
\text { the big }\end{array}$ & $\begin{array}{l}\text { Like this } \\
\text { size }\end{array}$ & $\begin{array}{l}\text { A little bit } \\
\text { big for me }\end{array}$ & This size is ok! & Ok & $\begin{array}{l}\text { This size could } \\
\text { be acceptable. }\end{array}$ \\
\hline
\end{tabular}

According to the data which was collected and analysed, $71.4 \%$ of the users accept and prefer the $140 \mathrm{~mm}$ size of the disc. Some of them claimed that the $140 \mathrm{~mm}$ size would match their fridge size better than the other two sizes. Another reason to choose $140 \mathrm{~mm}$ size would be the structure problem. In the picture 5, different date branches were designed in different levels and heights. While, this design needs motor moving up and down to engage with different branches. It would be tricky to make this part achieved and all branches are at different levels which would add extra height on the whole disc. Therefore, according to all the considerations, final disc size has been chosen $140 \mathrm{~mm}$ diameter. Meanwhile the inside branches would come into the disc in a same level. (Figure 4)

Seven small different sizes of date branches have been made and 6 users were asked to evaluate which size they like best. The sizes of these seven date branches are $70 * 10 \mathrm{~mm}, 70 * 11 \mathrm{~mm}, 70 * 16 \mathrm{~mm}$, 
$63 * 10 \mathrm{~mm}$, Figure $6,64 * 10 \mathrm{~mm}, 64 * 9 \mathrm{~mm}$ and $46 * 8 \mathrm{~mm}$, which have been glued on the $140 \mathrm{~mm}$ disc. (Figure 5)

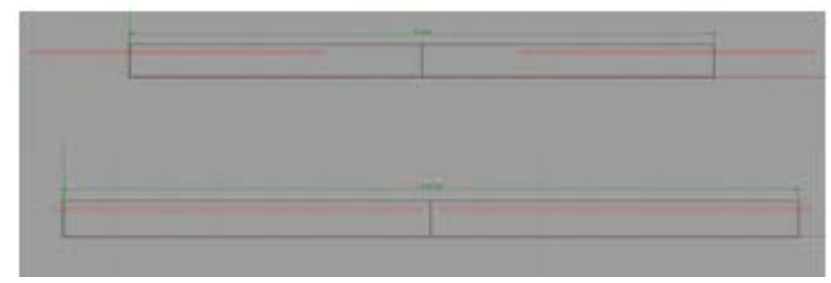

Figure 4

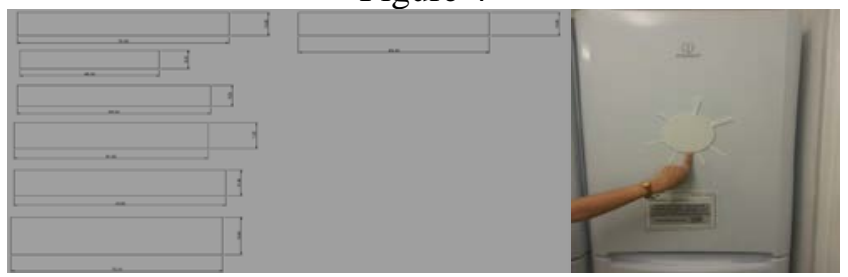

Figure 5

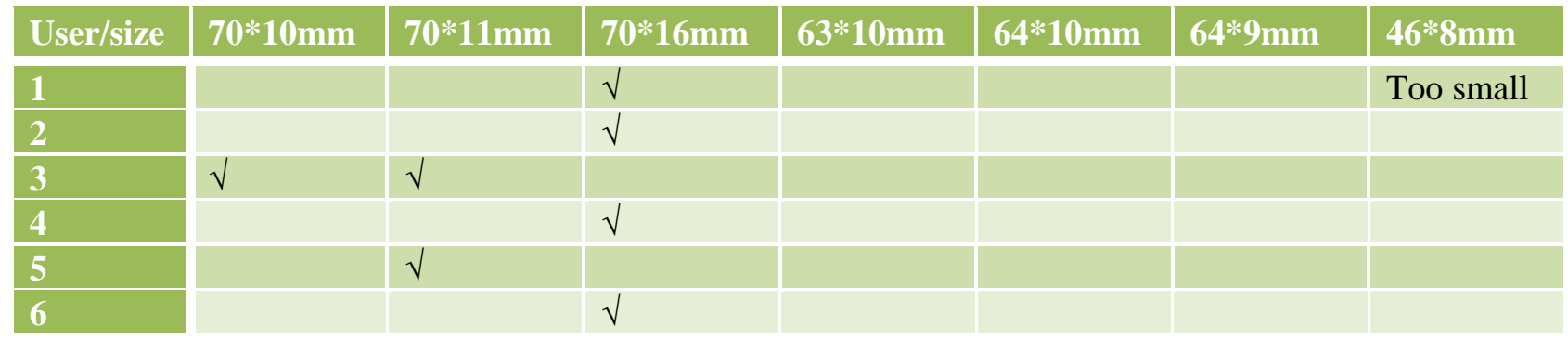

Chart 3

According to the users' selections, $66.7 \%$ of them have chosen $70 * 16 \mathrm{~mm}$ as the final branch size, which they thought would be nice and could match the $140 \mathrm{~mm}$ size of disc. Therefore, the final date branch has been designed with $70 \mathrm{~mm}$ length, $16 \mathrm{~mm}$ width and $1 \mathrm{~mm}$ thickness.

To set up the date branch and engage all the parts working, user needs to pull out the date branch. Hence, the branch needs a small part that could help user to grab and use it to pull them out.

Eleven models have been created based on the size of 3mm, $5 \mathrm{~mm}, 6 \mathrm{~mm}, 7 \mathrm{~mm}, 8 \mathrm{~mm}, 9 \mathrm{~mm}, 10 \mathrm{~mm}$, $11 \mathrm{~mm}, 12 \mathrm{~mm}, 13 \mathrm{~mm}$ and $14 \mathrm{~mm}$. Meanwhile, 7 users have been invited to take the hand knob test. In this test, users could try and feel all the knobs and evaluate which would be the perfect one for their fingers.57\% of the users chose $9 \mathrm{~mm}$ knob as they thought this size would be comfortable for them. One user claimed that she could tolerate the minimum size would be $6 \mathrm{~mm}$. And $28.6 \%$ users thought the largest size, $14 \mathrm{~mm}$, would be the best and most comfortable size for them.

\begin{tabular}{|c|c|c|c|c|c|c|c|c|c|c|c|}
\hline User/size(mm) & 3 & 5 & 6 & 7 & 8 & 9 & 10 & 11 & 12 & 13 & 14 \\
\hline User one & & & & & $\sqrt{ }$ & $\sqrt{ }$ & & & & & \\
\hline User two & & & & & & & & & & & $\sqrt{ }$ \\
\hline User three & & & $\sqrt{ }$ & $\sqrt{ }$ & $\sqrt{ }$ & $\sqrt{ }$ & $\sqrt{ }$ & $\sqrt{ }$ & $\sqrt{ }$ & $\sqrt{ }$ & $\sqrt{ }$ \\
\hline User four & & & & & & $\sqrt{ }$ & $\sqrt{ }$ & & & & \\
\hline User five & & $\sqrt{ }$ & $\sqrt{ }$ & & & & & & & & \\
\hline User six & & & & & $\sqrt{ }$ & $\sqrt{ }$ & & & & & \\
\hline User seven & & & & & & & & & & & $\sqrt{ }$ \\
\hline
\end{tabular}

Chart 4

Based on the data shown in the figure 3, final knob that designed on the date branch has been used 9mm length.

After finished all the prototypes, especially on the aesthetic model, this product has been shown to another 7 users who lives in China, have a child or two and full-time jobs. These seven users are the project's final consumers. 


\begin{tabular}{|c|c|c|c|c|}
\hline $\begin{array}{l}\text { Users/ } \\
\text { questi } \\
\text { ons }\end{array}$ & Size? & Colour? & Opinion & Advice \\
\hline Pang & Look nice & colourful & $\begin{array}{l}\text { It is good to help me remind the food } \\
\text { shelf-life }\end{array}$ & $\begin{array}{l}\text { If it is cheap, would give it a } \\
\text { try, like 20RMB }\end{array}$ \\
\hline Ming & Size is good & Look nice & $\begin{array}{l}\text { This product has potential market, } \\
\text { but curious if Chinese people would } \\
\text { like to use it? }\end{array}$ & $\begin{array}{l}\text { Make it cheaper; } 15-30 \text { pounds } \\
\text { are a little bit expensive to me. }\end{array}$ \\
\hline $\begin{array}{l}\text { Zhuan } \\
\text { g }\end{array}$ & Size is ok & $\begin{array}{l}\text { Nice and } \\
\text { colourful }\end{array}$ & "I would buy it." & $\begin{array}{l}\text { If it could have some sound } \\
\text { and more intelligent, this would } \\
\text { make this product better }\end{array}$ \\
\hline Ann & I & l & $\begin{array}{l}\text { Worry about the size of disc would } \\
\text { not be big enough for all the food }\end{array}$ & $\begin{array}{l}\text { Numbers look rigid, would like } \\
\text { to have a flash light rather than } \\
\text { numbers; }\end{array}$ \\
\hline Wei & Size is ok & $\begin{array}{l}\text { Colour is } \\
\text { nice }\end{array}$ & $\begin{array}{l}\text { The price is crucial, if it is cheap, } \\
\text { would buy one }\end{array}$ & $\begin{array}{l}\text { The words on the disc is a little } \\
\text { bit small }\end{array}$ \\
\hline Jun & l & l & $\begin{array}{l}\text { If children would use it, this product } \\
\text { would be fine }\end{array}$ & $\begin{array}{l}\text { If for adults, would like more } \\
\text { intelligent products }\end{array}$ \\
\hline Jing & Looks nice & $\begin{array}{l}\text { Colour is } \\
\text { simple }\end{array}$ & $\begin{array}{l}\text { I would give a try even if it is } 15 \\
\text { pounds }\end{array}$ & $\begin{array}{l}\text { My daughter would like it. Feel } \\
\text { it has a few patterns }\end{array}$ \\
\hline
\end{tabular}

According to the data above, $42.9 \%$ users wish to have a warning tone or a flash light which could help them remind the food date more clearly. 28.6\% users would like to add more cartoon pictures and patterns on the product, which they thought would attract their children's attention and allow children willing to assist them on reminding food date. Another $28.6 \%$ users mentioned that they like a more intelligent product rather than a simple one. $42.9 \%$ users claimed that the price of this product was crucial for them.

Therefore, in this evaluation, apparently some of the users still want to have a warning tone or a flash light to assist them on reminding food. And an appropriate price would be appealing more consumers.

This material needs to stick on the fridge by using magnet, so the material of its cover should be light and easy to mould. From Leif Terry's book on plastic (2004), some of the materials which might be suitable to use in this project have been listed in the Chart 6 .

\begin{tabular}{|c|c|c|}
\hline Material & Advantages & Usage \\
\hline $\begin{array}{l}\text { LDPE } \\
\text { ( Low- density } \\
\text { polyethylene) }\end{array}$ & $\begin{array}{l}\text { Recyclable, corrosion resistance, cheap, } \\
\text { easy to manufacture, moisture resistivity, } \\
\text { balance the intension and suppleness }\end{array}$ & $\begin{array}{l}\text { Bags, toys, car fuel tank, furniture, } \\
\text { chemical containers }\end{array}$ \\
\hline $\begin{array}{l}\text { Carbon fibre \& Epoxy } \\
\text { resin }\end{array}$ & $\begin{array}{l}\text { Easy to order, good strength-to-weight } \\
\text { ratio, No corrosive, Good chemical } \\
\text { resistance, could offer many colours, } \\
\text { good durability, Light }\end{array}$ & $\begin{array}{l}\text { Aerospace industry, ship, car, sports } \\
\text { goods, architecture, rail transport }\end{array}$ \\
\hline $\begin{array}{l}\text { PP } \\
\text { ( Polypropylene) }\end{array}$ & $\begin{array}{l}\text { Multiple choice on transparent and } \\
\text { colour, low density, recyclable, low cost, } \\
\text { manufacture is easy and flexible }\end{array}$ & $\begin{array}{l}\text { Furniture, package, food package, } \\
\text { folder, }\end{array}$ \\
\hline $\begin{array}{l}\text { PVC } \\
\text { (Polyvinyl Chloride) }\end{array}$ & $\begin{array}{l}\text { Easy to manufacture, Low cost, } \\
\text { toughness, Good UV condition, easy to } \\
\text { single mould, broad-spectrum }\end{array}$ & $\begin{array}{l}\text { Chemical containers, hand bag, } \\
\text { elastic toys, car tank, furniture }\end{array}$ \\
\hline $\begin{array}{l}\text { CAP \& PA } \\
\text { ( Cellulose acetate } \\
\text { propionate \& Nylon) }\end{array}$ & $\begin{array}{l}\text { Light, easy to manufacture, special } \\
\text { appearance design, multiple vision effect, } \\
\text { good elasticity, }\end{array}$ & $\begin{array}{l}\text { Handle of tools, toys, goggles, } \\
\text { helmet, toothbrush }\end{array}$ \\
\hline
\end{tabular}

\section{Chart 6}


Compared the advantages of each plastic, Polyvinyl Chloride and Polystyrene have been covered the more purple words than other plastic materials which mean they would be more suitable on making top and bottom cover for this product.

According to the report of Plastics News (2013), PVC and PE resin prices rise, while PS falls an average of 2 cents. Hence, the final material has been chosen PS to make the top and bottom cover.

\section{S.W.O.T. analysis}

\subsection{Strengths}

The function and operation to remind food shelf life are easy to handle with a clear eye-catching interactive surface. Add the eat-well-plate pattern on it, could teach parents how to keep their children live in a health way. Hence, through this product, user could be reminded of food date, reduce food waste, save money, and live in a healthy life.

\subsection{Weaknesses}

This product only can deal with a limited number of foods. The size and weight of this product also needs to take into consideration.

\subsection{Opportunities}

From figure 3, family with children would be target market and users, while shared/unrelated group could be a potential group in this project. According to many food waste reports and organisations, they appreciate people reducing food waste and keeping a healthy diet. Hence, including this design point would add extra value on this project.

\subsection{Threats}

The size and weight would still be one of biggest challenges in this project. Technology would include complicated programming and circuit board. Therefore, to test if technologies could work well has become another considerable issue in further development.

\section{References}

[1] Cadwallader, K.R., Weenen, H., 2002, Freshness and Shelf life of foods. America Chemical Society, Washington, DC

[2] Quested, T., Johnson, H., 2009, Final Report: Household Food and Drink Waste in the UK. WRAP. Banbury, ISBN: 1-84405-430-6

[3] Love Food hate waste. About Food Waste. WRAP, Information on http://england.lovefoodhatewaste.com/content/about-food-waste-1. Accessed 3rd July 2013. [4] Love Food hate waste. About Food Waste. WRAP, Information on http://england.lovefoodhatewaste.com/content/about-food-waste-1. Accessed 3rd July 2013. [5] Reflex printed plastics. Lenticular Effects. Information on http://www.reflex-print.co.uk/Default.asp?page=8. Accessed 15th September 2013. 